\title{
Challenging the cost of clinical negligence
}

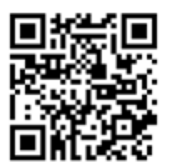

Healthcare professionals in South Africa (SA) are facing challenging times. As the clinical negligence claims environment in SA deteriorates, the effect is being felt not only by healthcare professionals but also by the wider public as a result of the strain that costs place on the public purse. We look at the current claims environment, and explain why a debate about reform is so important.

\section{The challenges}

There is growing recognition of the need for legal reform in SA, not only to reduce the burden of mounting costs but also to create a system that both ensures reasonable compensation for patients and allows for a fair and robust defence where necessary. An efficient and cost-effective legal system that works for patients and their families, as well as for healthcare professionals, is crucial.

In our experience at the Medical Protection Society (MPS), over the past 6 years there has been a deterioration in the overall claims environment for medical members. Our data indicate that between 2009 and 2015 the probable value of claims being brought against doctors has escalated, with claim sizes increasing by over $14 \%$ on average each year during that period. Our data also indicate that the estimation of the long-term average claim frequency for doctors in 2015 was around $27 \%$ higher than in 2009.

Not-for-profit mutual organisations such as MPS have an obligation to ensure that they collect sufficient subscription income to meet the expected future costs of claims against members, so they can be in a position to defend members' interests long into the future. If the current clinical negligence claims trend continues, it will result in higher costs for healthcare professionals.

The situation is also of concern to the SA government and has been described as a 'crisis' by Health Minister Dr Aaron Motsoaledi. 'The nature of the crisis is that our country is experiencing a very sharp increase - actually an explosion in medical malpractice litigation which is not in keeping with generally known trends of negligence or malpractice,' Motsoaledi said at a medicolegal summit in Pretoria in March 2015. 'The cost of medical malpractice claims has skyrocketed and the number of claims increased substantially. ${ }^{[1]}$

MPS does not believe that the deteriorating claims environment in recent times reflects a deterioration in professional standards. There are potentially a multitude of complex factors, some of them positive, that are contributing to the current claims experience, including:

- The lack of a patient-centred and robust complaints system is leaving many patients with litigation as the only viable avenue for redress. ${ }^{[2]}$

- The lack of an efficient and predictable legal process for handling clinical negligence claims allows the size of claims to increase and makes delays endemic, with no parties benefiting.

- The cost of settling a claim increases as time goes on. A protracted legal process can have a significant impact on the final costs of settling a claim, as it means that legal bills continue to mount and compensation can increase in size.

- Amendments to the provisions of the Road Accident Fund Act potentially result in attorneys refocusing their area of interest towards personal injury claims, clinical negligence in particular.

- Patients are increasingly aware of their rights under the Constitution and the Consumer Protection Act.

- Patient expectations are increasing, with many patients now expecting greater involvement in, and understanding about, their healthcare.
Alongside concerns about cost, there is a belief that the clinical negligence litigation system does not facilitate the efficient and fair resolution of disputes. Instead, the system is unnecessarily adversarial with frequent 'trial by ambush'. It also lacks transparency and is time consuming and expensive.

While the claims experience may not continue to deteriorate at its current pace, the experience to date merits serious consideration of legal reform.

\section{The debate}

The deterioration of the claims environment has a negative effect not only on the healthcare profession but also on wider society.

Legal and procedural reforms are required to begin to tackle some of the factors that have led to this claims experience and ensure a fairer and more efficient system for all parties. Added to this, a patient-centred, standardised complaints system should be developed to ensure that patient concerns are addressed, where possible, before they become a claim.

Any proposals to tackle the rising cost of clinical negligence need to be debated and explored at a public policy level because of the current effect of clinical negligence on the public purse. Dr Motsoaledi initiated the debate about reforms, and MPS has contributed to the debate by launching its policy paper 'Challenging the costs of clinical negligence: The case for reform' in Johannesburg on 10 November 2015. We are only one voice, however, and our reform proposals are not exhaustive. ${ }^{[3]}$

The lively and informative debate at the launch event highlighted some of the many interesting ideas for reform that should be considered. These include further thoughts on alternative dispute resolution, and how risk management can be used to prevent claims arising in the first place.

Prevention is an important theme, and defence organisations must continue to play their part to promote safe practice in medicine, with open disclosure being a crucial element. When organisations embrace open disclosure, it benefits all involved. Above all, it is the ethical thing to do.

\section{Our proposals}

1. Complaints process

- The development of a consistent, efficient, aligned and patientcentred complaints process that allows for local resolution.

\section{Frequency of claims}

- A Certificate of Merit be introduced.

- Further consideration of ways to encourage alternative dispute resolution.

\section{Pre-litigation resolution framework}

- The introduction of a pre-litigation resolution framework.

\section{Procedural changes}

- Procedural change to ensure:

- the exchange of factual witness statements

- early exchange of expert notices and summaries

- mandatory early experts meetings.

5. Limiting damages awards (general and special)

- A tariff of general damages is created in statute

- A limit on general damages 
- A limit on future care costs

- A limit on claims for loss on future earnings.

The importance of the debate, and engagement therewith, cannot be over-emphasised. ${ }^{[4]}$

Conflict of interest. Both authors are full-time employees of the Medical Protection Society (MPS). MPS is not an insurance company but a nonprofit mutual organisation.

\section{Graham Howarth}

Head of Medical Services: Africa, Medical Protection Society,

Victoria House, 2 Victoria Place, Leeds, UK

\section{Emma Hallinan \\ Director of Claims and Litigation, Medical Protection Society, Victoria House, 2 Victoria Place, Leeds, UK}

Corresponding author: G Howarth (graham.howarth@medicalprotection.org)

1. SA's shocking medical malpractice crisis. http://www.health24.com/News/Public-Health/SAsshocking-medical-malpractice-crisis-20150309 (accessed 29 December 2015).

2. Howarth GR, Tiernan J, Carstens P, Gillespie G. A good complaints system. S Afr Med J 2015:105(6):425-426. [http://dx.doi.org/10.7196/SAMJ.9358]

3. Challenging the cost of clinical negligence: The case for reform. http://www.medicalprotection.org/ southafrica/about-mps/our-policy-work (accessed 29 December 2015)

4. Howarth GR, Goolab B, Dunn RN, Fieggen AG. Public somnambulism: A general lack of awareness of the consequences of increasing medical negligence litigation. S Afr Med J 2014;104(11):752-753. [http://dx.doi.org/10.7196/SAM].8568]

S Afr Med J 2016;106(2):141-142. DOI:10.7196/SAMJ.2016.v106i2.10408

\section{This month in the $S A M J$...}

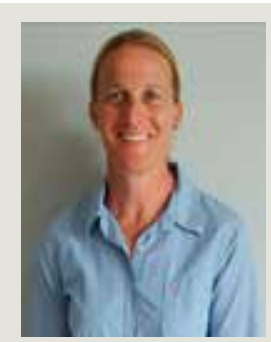

Dagmar Muhlbauer* is a lecturer in the Department of Emergency Medical Care and Rescue at the Durban University of Technology, KwaZulu-Natal. She holds a master's degree in emergency medical care, is serving a second term on the Professional Board for Emergency Care, and is the current chairperson of the Education Committee. She has directed her research efforts towards helicopter emergency medical services, as she has 16 years of experience in this field of prehospital emergency medicine. She believes that it is a very valuable resource, but that it needs to be utilised effectively in order to benefit patients in the South African context.

*Muhlbauer D, Naidoo R, Hardcastle TC. An analysis of patients transported by a private helicopter emergency medical service in South Africa. S Afr Med J 2016;106(2):201205. [http://dx.doi.org/10.7196/SAMJ.2016.v106i2.9919]

\section{The Lancet Commission}

Meara JG, Leather AJ, Hagander L, et al. Global Surgery 2030: Evidence and solutions for achieving health, welfare, and economic development. Lancet 2015;386(9993):569624. [http://dx.doi.org/10.1016/S0140-6736(15)60160-X]

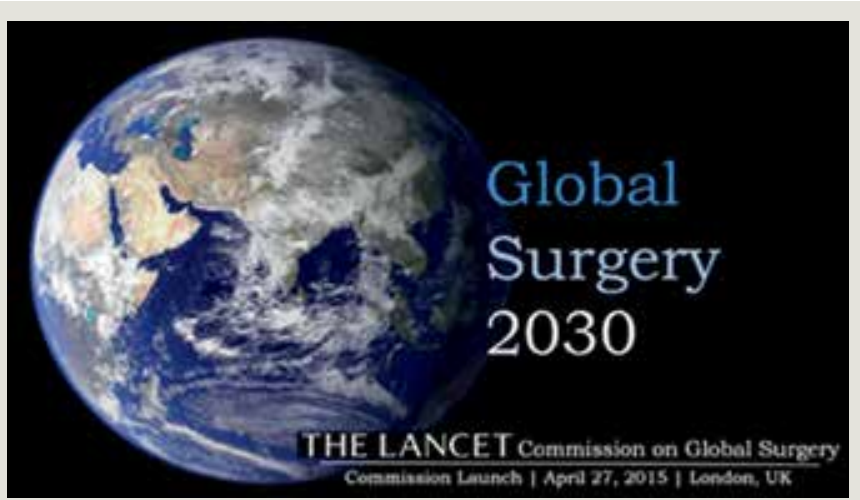

